\title{
IMPLEMENTATION OF E-BOOK BASED ON 3D PAGEFLIP PROFESSIONAL TO IMPROVE CONCEPTUAL UNDERSTANDING OF SCIENCE FOR ELEMENTARY SCHOOL STUDENTS
}

\author{
Arif Fudin ${ }^{1 *}$, Ristiana Dyah Purwandari ${ }^{2}$ \\ ${ }^{1}$ SD Negeri 1 karangreja, Purbalingga, INDONESIA \\ ${ }^{2}$ Universitas Muhammadiyah Purwokerto, INDONESIA
}

Received 26 May 2021 - Revised 30 August 2021 - Accepted 19 September 2021

\begin{abstract}
This study aims to determine the benefits of using e-book teaching materials as an alternative to improve conceptual understanding of science for Elementary School students. Students who have an understanding will be able to explain again the lessons they have learned based on their understanding so that learning will be meaningful. The method in this research is the literature study method. The type of this data is secondary data. The method in this research is literature study method. The data obtained were collected, analyzed, and concluded to get conclusions about the literature study. Based on the research results, literature studies from several research results and journal articles show that the benefit of e-book can improve conceptual understanding of science for Elementary School students.
\end{abstract}

Keywords: E-book, conceptual understanding of science, Elementary School

\section{INTRODUCTION}

Education plays an essential role in preparing the next generation of the nation. National education has the function of developing capabilities and shaping dignified national character and civilization in order to educate the nation's life. National education aims to develop the potential of students to become human beings who have faith and devotion to God Almighty, have a noble character, are healthy, knowledgeable, capable, creative, independent, and become democratic citizens, as well as being responsible.

Learning is one of the primary duties of the teacher. Learning is a process of managing a person's environment that is deliberately carried out so that it allows him to learn to perform or demonstrate certain behaviors as well . Learning is a process carried out by providing education and training to students to achieve learning outcomes [1].

Learning has components consisting of: a) teaching materials, b) learning media, c) learning facilities, d) learning objectives, e) learning methods, f) teachers, g) students [2]. Learning components are: a) students, b) educators, c) approaches and methods, d) media or tools, e) teaching materials, f) evaluation [3]. From these two opinions, it can be seen that the teaching material is one part of the learning component that cannot be eliminated.

Textbooks are a source of learning and teaching materials that are widely used in learning, including in science learning. Textbooks are books in a certain field of study, which are standard books, compiled by experts in that field for instructional purposes, which are equipped with suitable teaching facilities and are easily understood by users in schools and colleges so that they can support learning [4].

Textbooks are indeed conventional teaching materials as well as learning resources for students. The teaching materials used as learning resources and circulating in the market so far are still general and have not touched the potential, resources, and problems that each student has, so this has an impact on the further distance the subject matter is from the values that should be achieved by students. This happens because teachers tend to use ready-touse teaching materials without any desire to develop teaching materials following with the conditions encountered in the field during the learning process. The media used is still limited to powerpoints. In this case, the teacher has not been able to develop teaching materials and media that are interesting and challenging for students. Some student responses also said that science learning so far has only been oriented towards memorization from textbooks that have been provided by the school so that it seems boring because it is presented with interesting and unattractive materials. 
Science aims to help students understand science facts and concepts about natural phenomena and apply them to can develop and instill scientific attitudes in students. Science is not only concerned with students' mastery of facts, concepts, and scientific theories, but students are required to understand the process of how these facts, concepts and theories are found [5]. Given the importance of understanding concepts in science learning, students' ability to understand science concepts must be improved, because the value of understanding concepts means students are not only limited to knowing the concept, but students are also able to explain the lessons taught in their own sentences and can apply them in life [6].

Conceptual understanding is the individual's ability to understand a certain concept. A student already has an understanding of the concept if the student already knows the meaning of a concept [7]. From this opinion a student who has an understanding will be able to explain the lessons he has learned based on his own understanding so that learning will be meaningful.

\section{METHOD OF THE RESEARCH}

This research method is a literature study. The literature study method is a series of activities related to the method of collecting library data, reading and taking notes, and managing research materials [8]. The literature study is carried out by each researcher with the main objective of finding a basis for obtaining and building a theoretical basis, frame of mind, and determining provisional assumptions or also known as research hypotheses [9]. The data taken in this study is secondary data. Secondary data is data taken not from direct observers but the results of research by previous researchers in the form of textbooks, journals, and scientific articles. The data obtained were collected, analyzed, and concluded to get conclusions about the literature study.

\section{RESULT AND DISCUSSION}

\section{Science Fact}

Science studies the universe, both that which can be observed with the senses and that which is not observed with the senses. Science is a collection of knowledge arranged systematically, and in general its use is limited to natural phenomena [10]. Science emphasizes providing direct experience and training students to have problemsolving abilities [11]. Providing direct learning experiences through the use and development of conceptual understanding with the aim of understanding concepts and being able to solve problems.

Science learning aims so that students: (a) Develop curiosity and a positive attitude towards science, technology, and society. Developing process skills to investigate the natural surroundings, solve problems and make decisions, (b) Develop knowledge and understanding of scientific concepts that will be useful and applicable in life [12].

From some of the descriptions above, it can be concluded that science seeks to arouse human interest so that they want to increase their intelligence and understanding of nature, which is full of endless secrets. Giving science aims to make students understand science concepts and their interrelation, and be able to use scientific methods to solve the problems they face, they are more aware of the greatness and power of their Creator.

\section{Definition of Teaching Materials}

Teaching materials are all forms of material that are systematically arranged which are used to assist teachers or instructors in carrying out teaching and learning activities so as to create an ideal learning atmosphere [13]. Teaching materials are a set of materials that are systematically arranged, both written and unwritten so as to create a good learning environment. Teaching materials are subject matter that is systematically arranged, which is used by teachers and students in the learning process. Teaching materials not only contain material about knowledge but also contain skills and attitudes that students need to learn to achieve the standards set by the government [14]. From several opinions regarding the understanding of these teaching materials, it can be understood that teaching materials are learning components used by teachers as learning materials for students and helping teachers in carrying out teaching and learning activities in the classroom.

\section{Characteristics of Teaching Materials}

Teaching material can be said to be good and interesting if there are the following characteristics: (a) selfinstruction, namely teaching materials that can make students able to teach themselves with developed teaching materials. (b) Self contained, which is all subject matter from one unit of competence or sub-competence being learned contained in one teaching material as a whole. (c) Stand alone, the developed teaching materials do not depend on other teaching materials or do not have to be used together with other teaching materials. (d) Adaptive, teaching materials should have high adaptive power to the development of science and technology. (e) User friendly, namely every instruction and exposure to information that appears helpful and friendly to the user [15]. (C) 2021 by the authors; licensee PGSD UMP. This article is an open access article distributed under the terms and conditions of the Creative Commons Attribution License (http://creativecommons.org/licenses/by/4.0/). $\square$ ariffu93@gmail.com ${ }^{1}$, ristianadyah@yahoo.com ${ }^{2}$ ( ${ }^{*}$ Correspondence) 


\section{E-book Teaching Materials}

E-book is an abbreviation of electronic book, another name that is often used is a digital book in the form of softcopy that can be read via electronic devices such as computers or smartphones. E-book as electronic books can be read digitally on a computer screen, a special E-book reader (E-book reader), personal digital assistant (PDA), or even a smartphone. In other words, E-book are enjoyed and read on the screen rather than on sheets of paper and in electronic books there are also videos and audios as a complement to understand information easily. So an E-book is a book in digital or electronic form which usually contains information or a guide. This electronic book can only be opened and read through electronic devices such as computers, tablets and smartphones [16].

One of the applications that can be used to create an E-book is 3D PageFlip Professional. The 3D PageFlip Professional application is an application software used to create E-books, digital magazines, e-papers and others. 3D PageFlip Professional is a type of flip page professional software for converting Portable Document Format (PDF) files to flip-page digital publications. Each page of the PDF that is produced can be flipped (back and forth) like a real book. With the 3D PageFlip Professional software you can add videos, images, audio, hyperlinks and multimedia objects. In the 21st century there is competition in various fields of life, including education. We are faced with demands on the importance of quality human resources who are able to compete. Quality human resources generated by quality education can be the main force to solve problems..

From research with the title "Development of Scientific Learning E-Book Using 3D Pageflip Professional Program", Pageflip Professional 3D-based E-book have the advantages of digital interactive book design, flexible, efficient and effective because integrates text, images, audio, and video. The results of the research in the form of e-books of scientific study products were declared feasible by a team of experts $(97.33 \%$ material experts and $98.7 \%$ media experts), practitioners (97.33\% supervisors), and $90.6 \%$ with very good perception category teachers [17] From research with the title "Development of ELS-3D (3D Page Flip-Based Science Literacy E-Book) on Momentum and Impulse Materials", the result was that the ELS-3D (E-Book Science Literacy Based on 3D Page Flip) that had been developed had The overall validation rate is $90.34 \%$ and has very valid criteria both in terms of media and content, so that the ELS-3D that has been developed is suitable for use as a learning medium that can improve scientific literacy in momentum and impulse material [18]. From the results of research with the title "Development of ELS-3D (E-Book of Science Literacy Based on 3D Page Flip) on Momentum and Impulse Materials" the results obtained that the ELS-3D (E-Book of Science Literacy Based on 3D Page Flip) which has been developed has a high level of Overall validation is $90.34 \%$ and has very valid criteria both in terms of media and content, so that the ELS-3D that has been developed is suitable for use as a learning medium that can improve scientific literacy in momentum and impulse lessons [18].

Based on research with the title "Development of Metacognition-Based E-Book Teaching Materials Using 3D Page Flip on Redox Reaction Materials in Class X MIPA SMA Negeri 1 Muaro Jambi", shows that the assessment of materials teaching e-Book based on metacognition according to media experts, material experts, and teacher assessments each obtained an average answer score of 4.6 (very good); 4.8 (very good); and 4.6 (very good), then the percentage of student response scores was $89.8 \%$ (very good). Based on the development process starting from the validation of media experts and materials and research results, it can be concluded overall that this metacognition-based e-Book teaching material is very good for use as a learning medium and chemistry teaching materials [19]. From the research with the title "Development of 3D Pageflip-Based Electronic Teaching Materials in the Subject of the Application of Electronic Circuits at SMK Negeri 1 Kediri", the results were: (1) The validity of the PageFlip 3D software learning media got a score of 90.99 from the validator. \% which is included in the very valid category means that learning media can be used in learning activities, (2) Student responses to PageFlip 3D-based learning media in learning the application of electronic circuits get a score of $89 \%$ which is included in the very valid category, so it can be concluded that the media PageFlip 3D-based learning is very interesting for students for learning activities [20]. Kiar Vansa Febrianti, Fauzi Bakri, Hadi Nasbey with the title "Development of a Digital Physics Module Based on Discovery Learning on the Subject of Straight Motion Kinematics", it was found that the results of validation and trials showed that the percentage of achievement was $92.94 \%$ from material experts, $84.73 \%$. from media experts, $90.75 \%$ from high school physics educators, and $84.87 \%$ from high school students. In terms of module characteristics, the results obtained from the experts' assessment of selfinstructional $90.26 \%, 91.82 \%$ self-contained, $91.15 \%$ stand alone, $92.71 \%$ adaptive, and $91.67 \%$ user friendly with an average of all module characteristics of $91.52 \%$. The results of the evaluation of students after using the digital module were $89.10 \%$ in the C3 cognitive realm (using / applying) [21].

Based on the results of several previous studies, the validation results for the Ebook based on 3D Pageflip Professional teaching materials on average score very well in terms of material as well as in terms of media. In addition, the Ebook based on 3D Pageflip Professional also scores very well for self-instruction, self-contained, stand-alone, adaptive, and user-friendly assessments so that it can be categorized as a good and interesting teaching material. 


\section{CONCLUSION}

Based on the problems and research results of the literature study presented, it can be concluded that the implementation of Ebook teaching materials using 3D Pageflip Professional can improve conceptual understanding of science for elementary school students. The author hopes that this paper can be an alternative study for teachers and related parties in increasing the ability to understand science for elementary school students.

\section{REFERENCES}

[1] Soetomo. (1993) Dasar-dasar Interaksi Belajar Mengajar. Surabaya: Usaha Nasional.

[2] Hamalik, Oemar. (2013). Kurikulum dan Pembelajran. Jakarta: Bumi aksara.

[3] Slameto. (2010). Belajar \& Faktor-Faktor yang Mempengaruhinya. Jakarta: Rineka Cipta.

[4] Tarigan, \& Henry, Guntur. (1986). Menulis sebagai Suatu Keterampilan Berbahasa. Bandung: Penerbit Angkasa.

[5] Anggareni, N. W., Ristiati, N. P., \& Widiyanti, N. L. P. M. (2013). Implementasi strategi pembelajaran inkuiri terhadap kemampuan berpikir kritis dan pemahaman konsep IPA siswa SMP. Jurnal Pendidikan dan Pembelajaran IPA Indonesia, 3(1), 1-11

[6] Nahdi, Dede Salim, Devi Afriyuni Yonanda, \& Nurul Fauziah Agustin. (2014) Upaya Meningkatkan Pemahaman Konsep Siswa Melalui Penerapan Metode Demonstrasi Pada Mata Pelajaran IPA. Jurnal Cakrawala Pendas, 4(2), 9-16

[7] Mills, S. (2016). Conceptual Understanding : A Concept Analysis. The Qualitative Report, 21(3), 546-557.

[8] Zed, M. (2014). Metode Penelitian Kepustakaan. Jakarta: Yayasan Obor Indonesia.

[9] Kartiningrum, E. (2015). Panduan Penyusunan Studi Literatur. Lembaga Penelitian dan Pengabdian Masyarakat Politeknik Kesehatan Majapahit.

[10] Trianto. (2013). Desain Pengembangan Pembelajaran Tematik: Bagi Anak Usia Dini TK/RA dan Anak Usia Kelas Awal SD/MI. Jakarta :Kencana Prenada Media Group.

[11] Wibawa, I. M. C. (2014). Pengaruh Beberapa Model Pembelajaran Terhadap Pemahaman Konsep IPA Mahasiswa PGSD. In Prosiding Seminar Nasional MIPA.

[12] Kudisiah. (2018). Meningkatkan Hasil Belajar IPA Materi Gaya Menggunakan Metode Demonstrasi Pada Siswa Kelas IV SDN Bedus Tahun Pelajaran 2017/2018. Jurnal Ilmiah Mandala Education, 4 (2), 195-202.

[13] Hamdani. (2010). Strategi Belajar Mengajar. Bandung: Pustaka Setia.

[14] Prastowo, A. (2011). Panduan Kreatif Membuat Bahan Ajar Inovatif. Yogyakarta: Diva Press.

[15] Daryanto. (2013). Menyusun Bahan Ajar Modul untuk Persiapan Guru dalam Mengajar. Yogyakarta: Gava Media.

[16] Andina, Elga. (2015). Buku Digital dan Pengaturannya. Pusat Pengkajian Pengolahan Data dan Informasi Sekretariat Jenderal DPR RI.

[17] Raihan, Siti. (2018). Development of Scientific Learning E-Book Using 3D Pageflip Professional Program. Innovative Journal of Curriculum and Educational Technology, 2 (1), 7-14.

[18] Sumantri, Faradila Naba, \& Abd. Kholik. (2020). Pengembangan ELS-3d (E-Book Literasi Sains Berbasis 3D Page Flip) Pada Materi Momentum Dan Impuls. Inovasi Pendidikan Fisika, 9 (1), 479-483.

[19] Muhaimin, M., Bakar, A., \& Mindayula, E. (2016). Pengembangan Bahan Ajar E-Book Berbasis Metakognisi Menggunakan 3D Page Flip pada Materi Reaksi Redoks di Kelas X MIPA SMA Negeri 1 Muaro Jambi. Journal of The Indonesian Society of Integrated Chemistry, 8(1), 32-39..

[20] Rozi, \& Adam Fatchur. (2017). Pengembangan Bahan Ajar Elektronika Berbasis 3D Pageflip pada Mata Pelajaran Penerapan Rangkaian Elektronika di SMK Negeri 1 Kediri. Jurnal Pendidikan Teknik Elektro. 1 (1), 1-7.

[21] Febrianti, \& Kiar Fansa. (2017). Pengembangan Modul Digital Fisika Berbasis Discovery Learning Pada Pokok Bahasan Kinematika Gerak Lurus. Jurnal Wahana Pendidikan Fisika, 2(2), 18-26.

\section{http://jurnalnasional.ump/index.php/dinamika}

